\title{
SOLOW MULTI-CAPITAL GROWTH MODEL DESCRIBED BY A SYSTEM OF DIFFERENTIAL EQUATIONS ON TIME SCALES
}

\section{E. BRestovansKá And M. MedveĎ}

Abstract. In this paper we derive a system of differential equations on time scales of the Solow type corresponding to a production function depending on several capitals. A sufficient condition for the exponential stability of the steady-state solution with positive coordinates is proved. The obtained results are applied to the case of the Cobb-Douglas type production function.

Mathematics subject classification (2010): 34N05, 26E70, 97E40, 97M10.

Keywords and phrases: $\Delta$-derivative, time scales, multi-capital, stability, Cobb-Douglas function.

\section{REFERENCES}

[1] R. Agarwal, M. Bohner, D. O'Regan and A. Peterson, Dynamic Equations on time scales: A survey, J. Math. Comp. and Appl. Math., 141 (2002), 1-26.

[2] E. Accinelli And J. G. BRIDA, Population growth and the Solow-Swan model, International Journal of Ecological Economics and Statistics, 8, 7 (2007), 54-63.

[3] M. Bohner And A. Peterson, Advances in Dynamic Equations on Time Scales, Birkhaäuser, Boston, MA 2003.

[4] M. Bohner and A. Peterson, Dynamic Equations on Time Scales: An Introduction with Applications, Birkhaäuser, Boston, Basel, Berlin 2001.

[5] M. Bohner, J. Heim AND A. LiU, Solow models on time scales, CUBO, A Mathematica Journal 15, 1 (2013), 13-32.

[6] M. Bohner, J. Heim And A. LiU, Qualitative analysis of a Solow model on time scales, J. Concr. Appl. Math. 13, 3-4 (2015), 183-197.

[7] E. Brestovanská And M. MedveĎ, Solow differential equations on time scales: A unified approach to continuous and disrete Solow growth model, Differ. Equ. Appl., 5, 4 (2013), 473-488.

[8] S. Brianzoni, C. Mammana And E. Michetti, Local and global dynamics in discrete time growth model with nonconcave production function, Discrete Dyn. Nat. Soc., (2012), Article ID 536570, 22 pages, doc:10.1155/2012/53657.

[9] S. Brianzoni, C. Mammana And E. Michetti, Complex dynamics in the neoclassical growth model with differential saving and non-constant labour force growth, Stud. Nonlinear Dyn. Econom., 11, 3 (2007).

[10] S. Brianzoni, C. Mammana And E. Michetti, Global attractor in Solow growth model with differential savings and endogenic labour force growth, AMS Periodicals, Modelling Measurement and Control D 29, 2 (2008), 19-37.

[11] J. G. BRIDA AND E. L. MALDONADo, Closed form solutions to a generalization of the Solow growth model, Applied Mathematical Sciences, 1, 40 (2007), 1991-2000.

[12] J. G. BRida And J. S. Pereyra, The Solow model in discrete time and decreasing population growth rate, Economic Bulletin, 3, 41 (2008), 1-14.

[13] D. Cheban, C. Mammana And E. Michetti, Global attractors of quasi-linear non-autonomous difference equations: A growth model with endogenous population growth, Nonlinear Anal.: Serie B, 14 (2013), 1716-1731.

[14] J. HeIm, Economics and Finance on time scales, Dissertation, Faculty of the Graduate School, Missouri University of Science and Technology, 2012 (Advisor: M. Bohner). 
[15] S. HILGER, Ein Maßkettenkalkül Anwendung auf Zentrumsmannigfaltigkeiten, $\mathrm{PhD}$ thesis, Universität Würzburg, 1988.

[16] S. HiLger, Analysis on measure chains - A unified approach to continuous and discrete calculus, Results Math., 18 (1990), 18-56.

[17] S. HiLger, Differential and difference calculus - unified!, Nonlinear Analysis, TMA 30, 5 (1997), 2683-2694.

[18] J. Hoffacker ANd B. JAKSON, Stability results for higher dimensional equations on time scales, Int. J. Dynamical Systems and Differential equations, 3, No. 1-2 (2011), 48-58.

[19] T. KuliK AND C. C. TISDEll, Volterra integral equations on time scales, Basic qualitative and quantitative results with applications to initial value problems on unbounded domains, International Journal of Difference Equations, 3, 1 (2008), 103-133.

[20] M. G. MANKiW, D. Romer AND D. N. Weil, A contribution to the empirics of economic growth, The Quarterly J. of Economics, 107, 2 (1992), 407-437.

[21] V. Lakshmikantan, S. Sivasundram, B. Kayamkcalan, Dynamic Systems on Measure Chains, Kluwer Academic Publishers, Netherlands 1996.

[22] M. Medvě̃, Fundamentals of Dynamical Systems and Bifurcation Theory, Adam Hilger, Bristol, Philadelphia and New York 1992.

[23] R. M. Solow, Contribution to the theory of economic growth, Quarterly Journal of Economics, 70, 1 (1956), 65-94.

[24] R. M. SoLow, Technical change and the aggregate production function, Review of Economics and statistics, 39, 3 (1957), 312-320.

[25] T. W. SWAN, Economic growth and capital accumulation, Economic Record, 32, 2 (1956), 334-361.

[26] C. C. TISDELl AND A. ZAIDI, Basic qualitative and quantitative results for solutions to nonlinear, dynamic equations on time scales, Nonlinear Anal., 68, 11 (2008), 3504-3524.

[27] C. C. TISDEll AND A. H. ZAIDI, Successive approximations to solutions of dynamic dynamic equations on time scales, Comm. Appl. Nonlinear Anal., 16, 1 (2009), 61-87.

[28] P. VANHOUDT, Are public and private outlays for physical and knowledge capital equally productive? Applied Economics, 31 (1999), 1401-1410.

[29] J. VANHOUDT, How productive are capital investments in Europe? European Investment Bank (EIB). ISSN 0257-7755, 5, 2 81-106 (http://hdl.handle.net/10419/44797).

[30] H. WIESE, Intermediate Growth Theory, Springer-Verlag, Berlin, Heidelberg, New York 2006. 